\title{
PELAKSANAANTRIAS USAHA KESEHATAN SEKOLAH SD NEGERI DI WILAYAH KECAMATAN SOKARAJA, KABUPATEN BANYUMAS
}

\author{
Arie Rubrianto', Rakhmat Susilo \\ Fakultas Ilmu Kesehatan Program Studi Sarjana Keperawatan Universitas \\ Muhammadiyah Purwokerto \\ Jl. Raya Dukuh Waluh, PO BOX 202, Purwokerto 53182, Kembaran Banyumas, Indonesia \\ arierubriantogood1@gmail.com
}

\begin{abstract}
Abstrak
UKS memiliki peran penting dalam meningkatan derajat kesehatan siswa di sekolah. Namun kenyatannya, dilapangan penatalaksannya belum bisa secara optimal dikarenakan beberapa faktor. Tujuan: mengetahui pelaksanaan trias usaha kesehatan sekolah SD Negeri di Wilayah Kecamatan Sokaraja, Kabupaten Banyumas. Metode: Penelitian ini menggunakan desain deskriptif kualitatif. Teknik penentuan subyek penelitian ini peneliti menggunakan purposive sampling dan snowballing sampling. Informan penelitian ada 5 lima sekolah yang terdiri dari kepala sekolah, penanggung jawab UKS dan dokter kecil. Pengambilan data dengan observasi dan wawancara mendalam. Hasil: Pendidikan kesehatan yang diterapkan setiap sekolah selalu didemonstrasikan secara langsung pada saat pembelajaran maupun jam istirahat oleh dokter kecil. Pelayanan kesehatan yang dilaksanakan oleh UKS sekolah sudah berjalan dengan baik, namun hanya sebatas memberikan pertolongan pertama pada siswa atau guru yang sakit. Pemeriksaan lebih lanjut jika pasien tidak ada perubahan, UKS melakukan koordinasi atau dirujuk ke Puskesmas. Pembinaan lingkungan sehat dilakukan oleh pihak sekolah dengan membiasakan anak menjaga lingkungan sekolah untuk membuang sampah pada tempatnya. UKS juga rutin melakukan pemeriksaan kondisi atau status kesehatan siswa seperti tinggi badan, berat badan dan kesehatan gigi. TRIAS UKS di sekolah yang baik yaitu dengan menerapkan pelayanan kesehatan untuk setiap siswa, pendidikan kesehatan dan pembinaan lingkungan sehat.
\end{abstract}

Kata Kunci: SD Negeri, TRIAS UKS

\begin{abstract}
UKS (School's Health Clinic), widely known as school health clinic, has an important role in increasing the health status of students in school. However, in fact, the implementation of UKS has not been at its best due to several factors. Objective: Know out the description of the implementation of the trias UKS in Sokaraja District, Banyumas Regency in 2019. Method: This study used a qualitative descriptive design. The purposive sampling and snowballing sampling were used to determine the subjects of this study. There were 5 research informants in the school consisting of the principal, the persons in charge of UKS and a little doctor, a term used to describe students who meet the criteria and have been trained to participate in carrying out some of the efforts to maintain and improve health at school. Data retrieval by observation and in depth interviews. Results: Health education in each school was always implemented directly during learning and during breaks by the little doctors. The health services carried out by UKS have been running well, but it is only limited to providing first aid to the sick students or teachers. There would be further examination only if the patient did not get better, the UKS would do some coordinations then take the patients to the Puskesmas or known as public health centre. The development of a healthy environment was carried out by the school by accustoming children to maintain the school environment to dispose of trash in its place. In addition, UKS has also routinely checked the condition or health status of students by checking their height, weight and dental health. School health units in triassic good schools namely
\end{abstract}

Corresponding author:

Arie Rubrianto

arierubriantogood1@gmail.com 
by implementing health services for each student, healthful environmental health education and guidance.

Keywords: Public Elementary School, TRIAS UKS

\section{PENDAHULUAN}

Penelitian ini dilatar belakangi oleh pengalaman peneliti yang beberapa kali melihat dan memperoleh informasi dari masyarakat bahwa ada anak sekolah yang sakit saat berada disekolah kemudian belum mendapatkan penanganan yang tepat terhadap siswa yang sakit. Karena di sekolah masih kurang sarana dan prasarana untuk menangani siswa sakit ketika mengikuti kegiatan belajar. Pihak sekolah juga menyadari minimnya pengetahuan terkait pendidikan kesehatan di Sekolah.

UKS berperan dalam peningkatan derajat kesehatan peserta didik di sekolah. Peningkatan derajat kesehatan siswa tersebut dilakukan dengan penerapan trias UKS seperti pendidikan kesehatan, pelayanan kesehatan dan pembinaan lingkungan sehat (Apriani, 2018). UKS menurut Rahmadhani (2019) merupakan bagian usaha kesehatan masyarakat yang diberikan untuk siswa, guru dan karyawan sekolah. Pendidikan kesehatan yang diberikan melalui sekolah lebih efektif dalam memberikan informasi tentang kesehatan kepada masyarakat.

Hasil pengambilan data pada 4 Sekolah dari 30 sekolah didapatkan bahwa angka siswa sakit masing-masing sekolah setiap bulan ada 15-20 siswa setiap bulannya. Dari 4 sekolah hanya ada 1 sekolah yang memberikan penanganan secara baik pada saat ada siswa sakit. Hal ini karena didorong sudah terdapat adanya ruangan UKS yang memadai dan terdapat dokter kecil untuk membantu pelaksanaan program UKS.

Kecamatan Sokaraja adalah salah satu Kecamatan di Kabupaten Banyumas dengan jumlah Penduduk sebanyak 1,7 juta jiwa, serta jumlah Penduduk yang ada di Kecamatan Sokaraja sebanyak 57.407 jiwa (Data Agregat Kependudukan per Kecamatan, 2018). Saat ini di Kecamatan Sokaraja terdapat 30 SD Negeri. 3 SD Negeri di antaranya yaitu SDN 1 Sokaraja Wetan, SDN 2 Sokaraja Wetan dan SDN 1 Sokaraja Kidul. Berdasarkan survey awal pada 3 SDN di Kecamatan Sokaraja dan dida patkan bahwa data kelengkapan Sarana dan Prasarana masih sangat kurang, dan alat-alat lainnya masih kurang perhatian serius, belum maksimalnya kinerja struktur organisasi UKS, serta Pendidikan kesehatan baik dari guru, Puskesmas maupun pihak terkait masih san gat kurang dan belum merata. Sedangkan dalam program pelayanan Kesehatan pada siswa masih kurang maksimal, bila ada anak sakit dibawa ke ruang Guru dan mendapatkan pelayanan seadanya dari Bapak/Ibu Guru untuk kemudian dipulangkan ke rumah. Kondisi tersebut menjadikan kesan kesehatan siswa hanyalah tanggung jawab orang tua semata. Padahal dari program UKS tersebut bisa menangani siswa atau warga sekolah yang sakit.

Peneliti kemudian melakukan wa w an cara dengan Kepala UPK Sokaraja, berdasarkan hasil wawancara yang dilakukan, Kepala UPK Sokaraja menginformasikan bahwa absensi siswa yang sakit pada bulan Juli Tahun 2019 yang diperoleh dari penanggung jawab SD di 3 SDN tersebut (SDN 1 dan 2 Sokaraja Wetan serta SDN 1 Sokaraja Kidul) di karenakan batuk, pilek, radang tenggorokan, dan diare. Berdasarkan informasi yang diperoleh dari kepala UPK Sokaraja, sejauh ini Dinas Kesehatan Kabupaten Banyumas memang sudah memaksimalkan dalam menggalakan acara UKS dengan membuat perlombaan dokter kecil, sedangkan untuk pendidikan kesehatan yang terakhir adalah dari PAMSIMAS (Penyediaan Air Minum dan Sanitasi Masyarakat) namun kegiatan tersebut di nilai belum dilaksanakan secara optima.

Penelitian ini dilakukan dengan tujuan mengetahui gambaran pelaksanaan trias UKS di SDN seKecamatan Sokaraja Kabupaten Banyumas Tahun 2019.

\section{METODE PENELITIAN}

Desain penelitian menggunakan desain penelitian deskriptif kualitatif. Teknik penentuan subyek penelitian ini peneliti menggunakan purposive sampling dan snowballing sampling. Teknik purposive sampling digunakan untuk menentukan key informan atau informan pertama. Sedangkan snowball sampling adalah teknik pengambilan sampel sumber data yang pada awalnya jumlahnya sedikit tersebut belum mampu memberikan data 
yang lengkap, maka harus mencari orang lain yang dapat digunakan sebagai sumber data (Sugiyono, 2013). Pemilahan sampel dalam penelitian ini berdasarkan kriteria inklusi dan eksklusi, yaitu sebagai berikut:

a. Kriteria inklusi

Kepala sekolah mengizinkan guru dan kader kesehatan sekolah / dokter kecil dijadikan sebagai informan penelitian

b. Kriteria eksklusi

1) Informan tidak hadir pada saat dilakukan pengambilan penelitian

2) Infroman kurang kooperatif pada saat dilakukan penelitian

Informan penelitian ada 5 lima sekolah yang terdiri dari kepala sekolah, penanggung jawab UKS dan dokter kecil. Pengambilan data dengan observasi dan wawancara mendalam dengan menggunakan kuesioner (pedoman wawancara). Analisis menggunakan konten analisis tematik.

\section{HASIL}

1. Pendidikan Kesehatan (PENKES) di Sekolah Dasar

Sekolah memiliki peran dalam memberikan informasi dan pengetahuan. PENKES merupakan bagian dari upaya memberikan informasi dan pengetahuan bagi seluruh anggota di sekolah. Pemberian pendidikan kesehatan diharapkan dapat meningkatkan kesadaran akan pentingnya menjaga dan menerapkan perilaku kesehatan. Selama penelitian berlangsung peneliti menemukan beberapa tema dalam pelaksanaan pendidikan kesehatan disekolah, yaitu sebagai berikut:

a. Demonstrasi

Pendidikan kesehatan secara umum yang dilakukan setiap sekolah dengan cara mempraktekan / mendemostrasikan secara langsung pada siswa. Berikut adalah hasil wawancara dengan informan yaitu;

"Untuk peningkatannya itu yang pertama itu saya harus ada apa, pertama adalah meningkatan mindsetnya kemudian meningkatkan motivasinya untuk hidup sehat itu, lah ini yang pertama saya adakan lomba untuk kelas bersih, kelas sehat, itu satu semester penilaiannya kemudian pada waktu pengambilan raport itu di berikan reward itu berupa hadiah untuk kelas terbersih dan juga sekaligus kelas inovatif untuk juara satunya dua ratus ribu rupiah, juara dua seratus lima puluh ribu rupiah juara tiga seratus ribu rupiah ya ini saya harapkan adanya motivasi seperti itu alhamdulillah sekarang juga sudah berbenah seperti itu." (KS S-1).

Kondisi tersebut dibenarkan oleh pernyataan penanggung jawab UKS, dimana kegiatan pendidikan keseh atan secara langsung dipraktekan pada saat jam pembelajaran, yaitu sebagai berikut;

"Kebetulan kalau di SD itu belum ada ekstrakurikuler semisal di PMR nggih.di ancang-ancang belum ada si (nggih), paling-paling pembinaan, kadang-kadang kalau saya sendiri sebelum olahraga kadang-kadang memasuki itulah sesekali tentang kesehatan itu olahraga? di kesehatan olahraga itu juga ada teorinya juga ada saya masukkan disitu." (PJ UKS $\mathrm{N}-1$ )

b. Koordinasi

Pendidikan kesehatan dilakukan dalam upaya untuk meningkatkan pengetahuan peserta didik yang ada disekolah. Pembina UKS selalu berkoordinasi dengan pihak terkait guna meningkatkan pengetahuan anak didiknya. Berikut hasil wawancara, yaitu;

"Yah pertama memang dari pengetahuan pendidikan juga ada kemudian disini juga ada KKG Penjas itu sering nanti ketemu disana disatu kecamatan ada sering lah pertemuan rutin sebulan sekali di kecamatankecamatan, kemudian juga pernah mengikuti di Puskesmas juga ada." Arie menjawab pelatihan atau pembinaan nggih (PJ UKS N-1)

Pernyataan yang serupa juga disampaikan oleh informan lainnya tentang koordinasi dengan pihak Puskesmas, yaitu;

"Oh, kalau di Puskesmas Sokaraja itu setiap dua bulan sekali itu pasti akan ada pertemuan (ehm) ada pertemuan khususnya untukya UKS-an (itu khusus 
penanggung jawab semua ngih Pak) iya semua ya lah nanti dari situ kan dari tiap-tiap guru UKS atau yang mewakili itukan bila mana ada masalah yang kurang tahu di tanyakan ke (pihak terkait tersebut nggih) iya terkait secara resmi ya Puskesmas atau medis lah ya (nggih) sehingga dari situ kita akan mendapatkan ilmu baru (oh) dari ilmu itu nanti kita bisa langsung traktir kemana atau paling tidak anak jadi tau oh ini seperti ini gitu biasanya seperti itu" (PJUKS SS-2)

\section{Pelayanan Kesehatan}

Pelayanan kesehatan di sekolah diperlukan untuk meningkatkan derajat kesehatan semua warga yang berada di sekolah tersebut. UKS merupakan bagian integral dalam pelaksanaan pemberian pelayanan kesehatan. Peneliti menemukan beberapa tema yaitu;

a. Pemeriksaan rutin

Pemberian pelayanan kesehatan tidak harus yang sudah sakit, namun sekolah memberikan pelayanan kesehatan juga untuk mencegah anak tersebut sakit. Berikut ini adalah hasil wawancara dengan informan, yaitu;

"Pelayanan kesehatan yang pertama itu untuk siswa yang baru baik kelas satu sampai kelas enam itu pertama ada pengukuran tinggi badan dan berat badan kemudian juga pengukuran pentajaman mata ini rutin dilakukan setiap tahun kemudian juga kerja sama dengan Puskesmas itu ada pemeriksaan kesehatan secara berkala juga setiap hari jumat hadir saya sudah sampaikan ada pemeriksaan kesehatan". (KS S-1)

"Iya, oh ini tingginya sekian berat badan ada (nggih), ini dokter kecilnya hampir habis belum ada pelatihan lagi (oh) waktu sih mas." (PJ UKS M3)

b. Pertolongan pertama

Penanggung jawab UKS juga menjabarkan bahwa petugas UKS selalu menangani siswa yang mengalami / mengeluhkan sakit dengan memberikan pertolongan pertama. Berikut ini adalah hasil wawancara dengan informan, yaitu;
"Yah petugas UKS itu yang menangani sementara sebagai pertolongan pertama, kemudian bawa ke UKS, kemudian di lakukan pemeriksaan kenapa anakini. Terus nanti guru Pembina UKS akan membantu disitu jadi nanti di ketahui dulu penyebab apaanak itu.pusing atau yang lain kemudian di tangani bersama guru dan petugas UKS" (PJ UKS N-4)

c. Ketersedian sarana dan prasarana

Pembina UKS juga mempertegas pelayanan kesehatan yang diberikan disesuaikan dengan kondisi peralatan yang ada di sekolah. Dokter kecil maupun anggota UKS berusaha semakimal mungkin dengan melihat kondisi siswa yang sedang sakit. Apabila siswa masih bisa ditangani di sekolah maka tidak perlu dibawa ke Puskesmas, namun jika dirasa anggota UKS tidak sanggup dan kondisi siswa mengkhwatirkan maka langsung dibawa ke Pusksemas. Berikut ini adalah hasil wawancara, yaitu

"Yah di sesuaikan dengan situasi lingkungan sini, kemudian peralatan ada yang ada hehehe ya namanya pertolongan pertama ya jadi yang penting anak tertolong jangan sampai istilahnya sakit kok di biarkan ataupun tidak mendapatkan pertolongan, selanjutnya nanti di rujuk ke Puskesmas jadi kalau misalnya tidak ada yang sanggup dan tidak ada alatnya di rujuk ke Puskesmas". (PJ UKS N-4)

d. Pemahaman orang tua yang kurang

Pelaksanaan pemberian pelayanan kesehatan sendiri ditemukan beberapa kendala salah satunya peralatan dan pemahaman yang kurang oleh orang tua tentang kesehatan. Berikut ini adalah hasil wawancara dengan informan, yaitu;

"Kendalanya pertama perala tannya yang kurang memadai yah, terus kemudian kadang-kadang dukungan orang tua, juga kadang-kadang ada istilahnya kurang paham betul mengenai kesehatan itu, bagaimana kadang-kadang bagaimana istilahnya laporan anak hidup tidak jelas dibeli 
istilahnya orang tuayangadu kesini seperti itu jadi kendalanya wali murid kadang-kadang." (PJ UKS N-1)

3. Pembinaan Lingkungan Sehat di Sekolah Dasar

Pelaksanaan pembinaan lingkungan sehat di sekolah setiap sekolah memiliki kebijakan masing-masing. Pemaparan pembinaan lingkungan sehat ditemukan beberapa tema yaitu sebagai berikut;

a. Bersih dan rapi

Konsep dari pembinaan lingkungan sehat semua sekolah hampir sama dalam pelaksanaannya yaitu menerapkan lingkungan yang sehat dengan menjaga lingkungan sekolah supaya tetap bersih dan rapi. Oleh karena itu, setiap sekolah ditetapkan hari sehat untuk bisa peduli akan lingkungan yang sehat.

"Iya kalau pengadaan lingkungan sehat sementara ini kami adakan pada setiap jum 'at itu ada kerja bakti seperti itu" (KS S-1)

Pernyataan tersebut juga dipertegas oleh penanggung jawab UKS dilingkungan sekolah, yaitu sebagai berikut;

"Kebetulan disini adajuga kebersihan dilakukan hari sabtunya ya, jumat bersih kerja bakti untuk anak-anak kerja bakti membersihkan lingkungan ada rumput ada sampah dan kemudian comberan, tempat-tempat nyamuk di bersihkan jadi menurut jadwalnya itu setiap minggu." (PJ UKS N-1)

b. Mengingatkan siswa

Pelaksanaan penanggung jawab UKS juga selalu mengingatkan siswa untuk selalu menjaga lingkungan sekitar maupun menjaga kesehatanny a. Berikut ini adalah hasil wawancara, yaitu;

"Yah pemberian pengetahuan kepada anak-anak supaya membuang sampah pada tempatnya kemudian jangan jajan sembarangan, memilih jajanan yang benar begitu, kemudian untuk mencuci tangan sebelum makan, kemudian gosok gigi juga ada di sini programnya" (PJ UKSN-1)

c. Koordinasi
Pembinaan lingkungan yang sehat juga dilaksanakan dengan melakukan koordinasi dan bantuan dengan Puskesmas. Hal ini bertujuan untuk menghasilkan hasil yang maksimal, berikut ini adalah hasil wawancara, yaitu;

"Iya tadi ada sosialisasi kemudian ada kegiatan pemberantasan nyamuk, kemudian apa lagi kegiatan pemeriksaan gigi dan mulut, juga awal tahun itu murid kelas 1, bulan pertengahan ada penyuntikan imunisasi (bisa nggih) iya bisa kemudian ada lagi tapi agak lupa kegiatannya." (PJ UKS $U-5)$

d. Pengecekan

Pelaksanaan pembinaan lingkungan yang sehat harus rutin dilakukan pemeriksaan kesehatan diri. Penanggung jawab juga rutin melakukan pengecekan pada diri siswa berupa kebersihan diri, yaitu sebagai berikut;

"Di periksa kalau olahraga juga di periksa seminggu sekali, kalau pas olahraga itu habis sebelum olahraga atau sesudah olahraga." (PJ UKSN-1)

e. Membuang sampah sembarangan

Pelaksanaan lingkungan sehat juga ditemukan beberapa masalah atau hambatan salah satunya siswa masih membuang sembarangan. Berikut ini adalah hasil wawancara, yaitu;

"Kesadaran ya bu ya, kadang-kadang anak diberi tahu berulang kali tetap saja ada yang buang sampah sembarangan, kemudian misalnya suruh cukur rambut, cukurnya malah kurang pas masih kadang-kadang niruniru artis apa bagaimana yah?" (PJ UKS N-1).

\section{PEMBAHASAN}

1. Pendidikan Kesehatan di Sekolah Dasar Hasil penelitian didapatkan bahwa pendidikan kesehatan dijalankan oleh UKS dengan cara mendemonstrasikan secara langsung pada siswa. Pihak sekolah juga sudah melakukan koordinasi dengan Puskesmas guna meperdalam dan memperluas pengetahuan siswa. Pendidikan kesehatan merupakan salah satu bentuk upaya penyampain materi 
untuk menambah informasi dan mengubah perilaku seseorang.

Hasil tersebut menjelaskan bahwa pelaksanan pendidikan kesehatan UKS dilingkungan sekolah baik. Pendidikan kesehatan UKS yang baik digambarkan dengan terlaksananya pendidikan kesehatan secara baik dan rutin pada peserta didik seperti penerapan PHBS. Menurut Rahmadhani (2019) pendidikan kesehatan pada UKS bertujuan untuk meningkatkan derajat kesehatan peserta didik dan sebagai upaya mencegah dan pemberantasan penyakit menular dengan menerapkan sikap, perilaku dan kebiasaan hidup sehat. Penelitian Amin (2015) menjelaskan bahwa pemberian pendidikan kesehatan di lingkungan sekolah sudah baik dengan nilai presentase $88 \%$. Kondisi tersebut dibuktikan dengan rutinya pemberian pengetahuan berupa PHBS dan tanggung jawab terhadap kesehatan dirinya sendiri.

Menurut Tim Pembina UKS (2009) bahwa PENKES adalah salah satu cara untuk membina siswa supaya dapat tumbuh kembang sesuai dengan umurnya, serta sehat secara fisik, mental d an sosial dan menyiapkan siswa supaya dapat berperan saat ini ataupun masa depan. Hal demikian juga sejalan dengan pengertian dari UKS itu sendiri menurut Setyo (2012) UKS adalah suatu kegiatan yang dilaksanakan dalam upaya peningkatan kemampuan dan ketrampilan hidup sehat dan peningkatan derjat siswa pada usia dini.

\section{Pelayanan Kesehatan di Sekolah Dasar}

Hasil wawancara didapatkan bahwa TRIAS UKS pada pelayanan kesehatan di sekolah dasar bahwa sekolah sudah menerapkan pelayananan secara baik. Hal ini didukung dengan peran dokter kecil yang siap tanggap dalam menangani siswa atau temannya yang sedang sakit.

Hasil wawancara ditemukan beberapa kendala dalam pelaksanannya seperti sarana dan prasarna yang belum memadai. Hal ini menyebabkan pasien belum dapat secara optimal dalam mengatasi masalah siswa sakit. Oleh karena itu, UKS bekoordinasi dengan pihak Puskesmas untuk mendapatkan pertolongan yang secara tepat dan tepat bagi siswa sakit. Hasil ini didukung oleh hasil penelitian Amin (2015) bahwa pelayanan kesehatan disekolah tergolong dalam kategori baik pada pelaksanannya dengan presentase $76.0 \%$. Kondisi tersebut dibuktikan oleh sekolah yang sudah memberikan pengawasan dan pemeriksaan secara rutin pada peserta didiknya.

Sekolah memiliki tanggung jawab dalam merawat dan menjaga kesehatan setiap peserta didiknya. Permasalahan kesehatan yang sering ditumui pada anak usia sekolah dasar yaitu kebersihan diri dan lingkungan misalnya gosok gigi yang baik dan benar ada 124 kasus $37 \%$ dari 336 siswa yang mengalami masalah gigi, serta masalah kebiasaan cuci tangan pakai sabun oleh siswa. UKS sebagai salah satu tempat dalam meningkatkan derajat kesehatan siswa, jika dalam pelaksanaan TRIAS UKS dengan baik dan benar (Prasetyo, 2014).

3. Pembinaan Lingkungan Sehat di Sekolah Dasar

Pembinaan lingkungan yang terlaksana dilingkungan sekolah sudah dilaksanakan secara baik. Kondisi tersebu t dapat dilihat dengan dilaksanakannya kegiatan rutin seperti jumat sehat, diman a pada kegiatan ini siswa diajak untuk bisa menjaga lingkungan sekolah yang sehat. Kegiatan ini untuk melatih murid untuk dapat melaksanakan PHBS dilingkungannya. Kurniawan (2015) menjelaskan bahwa penanaman PHBS di lingkungan sekolah merupakan suatu langkah dalam peningkatan hidup sehat dan pencapaian derajat kesehatan yang tinggi.

Mayangsari (2014) dalam penelitiannya menjelaskan bahwa UKS memiliki fungsi untuk penyaluran utama dalam membina semua siswa untuk bisa hidup secara sehat. Namun, pada kenyataanya pelaksanannya masih kurang di Sekolah Dasar. yang berfungsi sebagai saluran utama pembinaan kesehatan terhadap peserta didik, terasa sangat 
kurang dalam pelaksanaannya di Sekolah Dasar. Kondisi tersebut dapat dilihat dengan masih rendahnya perilaku hidup bersih dan sehat pada siswanya.

\section{KESIMPULAN}

1. Pendidikan kesehatan yang diterapkan setiap sekolah selalu didemonstrasikan secara langsung pada saat pembelajaran maupun jam istirahat oleh dokter kecil.

2. Pelayanan kesehatan yang dilaksan akan oleh UKS sekolah sudah berjalan dengan baik, namun hanya sebatas memberikan pertolongan pertama pada siswa atau guru yang sakit. Pemeriksaan lebih lanjut jika pasien tidak ada perubahan, UKS melakukan koordinasi atau dirujuk ke Puskesmas.

3. Pembinaan lingkungan sehat dilakukan oleh pihak sekolah dengan membiasakan anak menjaga lingkungan sekolah untuk membuang sampah pada tempatnya. UKS juga rutin melakukan pemeriksaan kondisi atau status kesehatan siswa seperti tinggi badan, berat badan dan kesehatan gigi.

4. Diharapkan pihak sekolah untuk selalu melakukan pembenahan diri dan koreksi dalam peningkatan kualitas pembelajaran yang baik dan optimal dengan terciptanya lingkungan yang sehat dan angka kesehatan dari siswa dan guru cukup tinggi.

5. Penelitian ini diharapkan dapat ditleliti oleh peneliti berikutnya dengan desain deskripsi korelasi, dimana untuk menganalisis hubungan faktor berpengaruh terhadap keberhasilan pelaksanaan TRIAS UKS.

\section{DAFTAR PUSTAKA}

Amin. (2015). Pelaksanaan Program Usaha Kesehatan Sekolah (UKS) Di Sekolah Dasar Neger Se-Kecamatan Alian Kabupaten Kebumen Tahun Ajaran 2015/2016. Skripsi. Universitas Negeri Semarang

Apriani. (2018). Pelaksanaan Trias Usaha Kesehatan Sekolah (UKS) di Sekolah Dasar. Jurnal Keolahragaan, 6 (1).

Kurniawan. (2015). Pelaksanaan Usaha Kesehatan Sekolah(UKS) Di SD Negeri 05 Kalumbuk Kecamatan Kuranji Kota Padang. Jurnal. Universitas Negeri Padang

Mayangsari. (2014). Pelaksanaan Program Usaha Kesehatan Sekolah Dalam Upaya Meningkatkan Derajat Kesehatan Pada Anak Usia Sekolah Dasar di Lombok Timur. Jurnal Kedokteran Yarsi 22 (2)

Prasetyo. (2014). Pelaksanaan Program Usaha Kesehatan Sekolah Dalam Upaya Meningkatkan Derajat Kesehatan Pada Anak Usia Sekolah Dasar di Lombok Timur. Jurnal Kedokteran Yarsi, 22 (2).

Rahmadhani. (2019). Ilmu Kesehatan Masyarakat Untuk SMK Farmasi I. Sleman: CV Budi Utama.

Setyo. (2012). Pendidikan Kesehatan. Artikel Ilmiah. UNY

Sugiyono. (2013). Metode Penelitian Kuantitatif, Kualitatif, dan $R \& D$. Bandung: CV. Alfabeta 